DOI: https://doi.org/10.47405/mjssh.v6i11.974

\begin{tabular}{|c|c|}
\hline 4.581 & Malaysian Journal of Social Sciences and Humanities (MJSSH) \\
\hline $\begin{array}{l}\text { Malaysian Journal of } \\
\text { Social cciences and }\end{array}$ & Volume 6, Issue 11, November 2021 \\
\hline (MJ-SSH) & e-ISSN : 2504-8562 \\
\hline & $\begin{array}{l}\text { Journal home page: } \\
\text { www.msocialsciences.com }\end{array}$ \\
\hline
\end{tabular}

\title{
Knowledge Level on Bagworm in Oil Palm and its Control Using Integrated Pest Management (IPM) Practices Among Independent Oil Palm Smallholders in Johor
}

\author{
Hasmiza Desa ${ }^{1}$, Nursuhana Dahari' ${ }^{1}$, Nur Hanani ${ }^{1}$ \\ 1Malaysian Palm Oil Board, (MPOB), Malaysia
}

Correspondence: Hasmiza Desa (hasmiza.desa@mpob.gov.my)

\begin{abstract}
Bagworm (Psychidae) and nettle caterpillars (Limacodidae) are among the major insect pests of oil palm in Malaysia. Bagworm from the species Metisa plana is the most destructive insect pests compared to nettle caterpillar in oil palm plantations. Outbreaks of bagworms were frequently occurred in various areas own by independent oil palm smallholders in Johor. At present, no scientific study has been conducted to indicate the level of knowledge among the independent oil palm smallholders on bagworm and its control, especially using the Integrated Pest Management (IPM) practices. Therefore, this study was conducted to determine knowledge level on bagworm and its control using IPM among 313 independent smallholders in three infestation areas in Johor, which are Mukim Chaah Bahru, Mukim Chaah, Mukim Paloh and Mukim Chamek. Data were collected by interview guided with a questionnaire consisting 23 questions regarding bagworm and its IPM practices. Most of the respondents are more than 51 years $(61.1 \%)$, with $77.7 \%$ males and $22.3 \%$ females. They are mostly having primary $(47.1 \%)$ and secondary $(47.5 \%)$ school qualifications. This study found that most of the respondents have a basic understanding of bagworm in oil palm and its control measures using IPM practices, but their knowledge is still at a low level. Correlation analysis showed a significant relationship between the level of knowledge on bagworm and its control methods with race, education level and field management experience among the respondents. Therefore, more focus should be given by extension agents to enhance smallholder knowledge on bagworm management, especially in the potential and affected areas in Johor.
\end{abstract}

Keywords: Bagworm, integrated pest management practice, knowledge, smallholder, oil palm

\section{Introduction}

As of December 2016, a large number of smallholders' oil palm areas in the District of Batu Pahat, Johor were affected due to bagworm infestation. The study focuses in Johor because of statistics showed that Johor has the highest affected area due to bagworm infestation in Malaysia and due to time and cost constraint to conduct the study. Chemicals and Integrated Pest Management Practices (IPM) are among the control methods available for smallholders to choose in managing the bagworms infestation. The IPM practices have been recommended to smallholders by MPOB to control bagworms infestation. However, based on field observation, most of the smallholders are still using chemical pesticides rather than IPM practices. The reasons could be because of lack of knowledge in controlling the bagworm infestation using IPM. Hence, it is important to carry out a survey to determine the knowledge level on bagworm in oil palm and IPM practices among independent oil palm smallholders in Johor. 


\section{Literature Review}

Malaysia is the second world largest player in oil palm industry. Currently, there are 5.85 million hectares of oil palm planted areas in Malaysia which comprise of private plantations, organized smallholders and independent smallholders. The independent oil palm smallholder sector plays a significant contribution in the Malaysian oil palm industry as their planted areas of 976,892 ha, accounting for $16.6 \%$ are owned by this group (MPOB, 2018). According to Malaysian Palm Oil Board Licensing Regulations (2005), the oil palm smallholding in Malaysia are those farmers who own oil palm land in aggregate less than 40.46 ha (100 acres).

Bagworm (Metisa plana) is one of the most destructive pests in oil palm plantations. Outbreaks of bagworm were occurred frequently. Bagworm (Psychidae) and nettle caterpillars (Limacididae) are major pests of matured oil palm. According to Basri et al. (1988), bagworm species M. plana attack more serious than nettle caterpillars, damaging 10,532 ha between 1981 and 1985, while over only 538 ha were attacked by nettle caterpillars (Norman \& Basri, 1992). The spread of the attacks by various bagworms species such as M. plana, Pteruma pendula and Mahasena corbetti were reported increased steadily from 2000 to 2005 , covering damage areas of 19,151 ha in the country (Norman \& Basri, 2007).

M. plana outbreaks are a recurring issue, particularly in Peninsular Malaysia's Southern Perak. Due to a drop in photosynthetic rate, a moderate defoliation (10-13\%) can result in a yield reduction of 30-40\% over two years. It was discovered that insect defoliation in fronds with a number between 2 and 6 can reduce yield by $10 \%$ to $13 \%$, resulting in a 44 percent drop in production. Smallholders will find it easier to implement control management through mass trapping with pheromones. The effectiveness of numerous typical sticky trap designs for catching male moths, as well as the possibility of using them for pest control, has been noted. In Papua New Guinea, Charles (2008) developed the Integrated Management Practices for bagworms, which included hand collection from young palms, removal of natural host plants from near oil palm growing areas, maintenance of good ground covers for beneficial insects, precise insecticide targeting by trunk injection, and biodiversity management. According to Basri (1993), insect defoliation in fronds with a number of 2 to 6 might result in a 44 percent production drop.

According to Kalidas (2012), managing the insect population to keep it below economic threshold levels is critical for reducing losses. Integrated management techniques based on the newest low-cost technology must be created for this purpose, ensuring the oil palm industry's long-term viability. Basri et al. (1995), reported that parasitoids are important in regulating the bagworm population. Natural enemies such as Apanteles sp., Xanthopimpla sp., Pediobius sp., and Brachymeria sp. have been found to feed bagworm larvae in Malaysia, according to Sankaran and Syed (1972). Their populations are reliant on the availability of refuge and food supplies (nectar) given by the oil palm ecosystem's beneficial plants. In young oil palm plantations, solar radiation reaches the ground, allowing diverse related flora to flourish, resulting in high levels of larval parasitism of up to $95 \%$.

The article by Kalidas (2012) entitled "Pest Problems of Oil Palm and Management Strategies for Sustainability" was recommended to overcome the bagworm infestation. Conservation of natural enemies of pests, as well as producing pollen and nectariferous plants in the field, were among the sustainable management options used such as Cassia cobanensis and Antigonon leptopus, cultivation of pest tolerant varieties, inundative or inoculative release of bioagents like Trichogramma spp., pesticides should not be used in a discriminatory manner, collection of the naturally occurring virus, multiplication in large quantity and release against the target pests, maintenance of hygienic conditions in orchards by eliminating all pest breeding locations, penetration of the sunlight into the garden by cutting the intermingling leaves and regularly monitoring the pest population. High daytime temperatures (highest temperature) may promote rapid evaporation of the pheromone, reducing the material's durability.

According to Morin and Mariau (1971), oil palm pests have been controlled mainly by the use of insecticides. An important part of any sustainable production system is by practicing the Integrated 
Pest Management. Effective management methods are known for some pests and diseases, but generally not effectively applied by smallholders. Furthermore, there is a demand for newer and more sustainable measures, which reduce over dependency on the use of chemical pesticides. A better understanding of symptoms and pest ecology is required to achieve better pest management. Also, awareness of oil palm key pests needs to be well disseminated within the palm oil industry, in particular the independent oil palm smallholders.

In his article "Integrated Pest Management: Historical Perspectives and Contemporary Developments," Kogan (1998) outlines the following components of IPM: "Integration," which refers to the harmonious use of several methods to control the impact of one or more pests ; "Pest," which refers to all organisms that are harmful to humans, including animals, pathogens and weeds, invertebrates and vertebrates; and Management is a term that refers to a collection of rules or decisions that are based on ecological principles as well as economic and social factors.

According to Maho and Godswill (2008), the Integrated Pest Management approach must be implemented in order to develop a long-term and competitive agricultural system. IPM is a multidisciplinary decision support system for the selection and use of pest control strategies that is harmoniously coordinated into management plan and based on cost-benefit evaluations that consider the interests of producers, society, and the environment. To reduce unacceptable levels of agricultural damage, this strategy coordinates the use of pest biology, pathogen biology, environmental information, and available technology.

As palms age, less and less solar radiation reaches the ground, resulting in the survival of only shadeloving ground cover species, which do not necessarily support mature forms of most natural enemies such as predators or parasitoids. Four plant species found in the oil palm ecosystem were found to be effective for bagworm management by extending the life duration of adult parasitoids. Cassia cobanensis, Crotalaria usaramoensis, Antigonon leptopus, and Euphorbia heterophylla were among the species studied (Sankaran \& Syed, 1972).

\section{Methodology}

The population for this study comprises oil palm independent smallholders registered with Pusat TUNAS at Mukim Chaah Bahru, Mukim Chaah, Mukim Paloh and Mukim Chamek in Johor. As of 31 January 2014, there were 1,621 smallholders in these four areas. Proportionate and simple random sampling was employed in this study. Based on Krejcie and Morgan (1970), the total sample size for the study was 313 smallholders.

The study employed a survey research methodology using an interview administrated questionnaire to gather information pertaining to knowledge of oil palm smallholders on bagworm in oil palm and its control using Integrated Pest Management (IPM) practices. The interview was conducted by field extension agents (TUNAS officers). A total of 23 questions regarding bagworm and its control practices were developed covering identification of bagworms and other pests, symptoms of bagworm infestation, types of control application, smallholder's awareness regarding available IPM practices, sources of information on IPM practices, types of IPM practiced by smallholders, constrains or problems faced by smallholders in adopting IPM.

\section{Result and Discussion}

\section{Socio-demographic characteristics of respondents}

Based on data in Table 1, a total of $61.1 \%$ of respondents with age more than 51 years old and followed by $15.6 \%$ of respondents between 31 and 40 years old. The age category 41 to 50 years old $(13.4 \%)$ is the third largest group and the remaining are categories between 21 to 30 years old (6.7\%). Only 3.2\% of respondents were in the young category with age of less than 20 years old. 
DOI: https://doi.org/10.47405/mjssh.v6i11.974

Table 1: Socio-Demographic Profile of Respondents

\begin{tabular}{|c|c|c|c|}
\hline Respondents profile & Category & Frequency (n) & Percentage $(\%)$ \\
\hline \multirow[t]{5}{*}{ Age } & $<20$ years old & 10 & 3.2 \\
\hline & 21 - 30 years old & 21 & 6.7 \\
\hline & 31 - 40 years old & 49 & 15.6 \\
\hline & $41-50$ years old & 42 & 13.4 \\
\hline & $>51$ years old & 192 & 61.1 \\
\hline \multirow{2}{*}{ Gender } & Male & 244 & 77.7 \\
\hline & Female & 70 & 22.3 \\
\hline \multirow[t]{6}{*}{ Monthly Income } & $<\mathrm{RM} 1000$ & 82 & 26.1 \\
\hline & RM 1001 - RM 2000 & 123 & 39.2 \\
\hline & RM 2001 - RM 3000 & 86 & 27.4 \\
\hline & RM 3001 - RM 4000 & 17 & 5.4 \\
\hline & RM 4001 - RM 5000 & 3 & 1.0 \\
\hline & > RM 5001 & 3 & 1.0 \\
\hline \multirow[t]{2}{*}{ Status } & Full Time & 133 & 42.4 \\
\hline & Part Time & 181 & 57.6 \\
\hline \multirow[t]{3}{*}{ Race } & Malay & 89 & 28.3 \\
\hline & Chinese & 193 & 61.5 \\
\hline & Indian & 32 & 10.2 \\
\hline \multirow[t]{3}{*}{ Education } & Primary & 148 & 47.1 \\
\hline & Secondary & 149 & 47.5 \\
\hline & College/University & 17 & 5.4 \\
\hline \multirow{5}{*}{$\begin{array}{l}\text { Experience in } \quad \text { field } \\
\text { management }\end{array}$} & $<10$ years & 54 & 17.2 \\
\hline & $10-20$ years & 177 & 56.4 \\
\hline & 21 - 30 years & 56 & 17.8 \\
\hline & $31-40$ years & 20 & 6.4 \\
\hline & $>40$ years & 7 & 2.2 \\
\hline \multirow[t]{5}{*}{ Overall Field Size (ha) } & $<1.55 \mathrm{ha}$ & 67 & 21.3 \\
\hline & $1.55-2.55$ ha & 117 & 37.3 \\
\hline & $2.56-3.55$ ha & 69 & 22.0 \\
\hline & $3.56-4.55$ ha & 23 & 7.3 \\
\hline & $>4.55$ ha & 38 & 12.1 \\
\hline \multirow[t]{4}{*}{ Distance Field to House } & $<1 \mathrm{~km}$ & 71 & 22.6 \\
\hline & $1-10 \mathrm{~km}$ & 185 & 58.9 \\
\hline & $11-20 \mathrm{~km}$ & 58 & 18.5 \\
\hline & $>20 \mathrm{~km}$ & 0 & 0.0 \\
\hline \multirow{4}{*}{$\begin{array}{l}\text { Frequency of Field Visit } \\
\text { (monthly) }\end{array}$} & $1-2$ times & 102 & 32.5 \\
\hline & $3-4$ times & 88 & 28.0 \\
\hline & $4-5$ times & 49 & 15.6 \\
\hline & More than 5 times & 75 & 23.9 \\
\hline \multirow{5}{*}{$\begin{array}{l}\text { What are the major } \\
\text { problem in oil palm } \\
\text { management in field? }\end{array}$} & Fertilizer Application & 42 & 13.4 \\
\hline & Disease Control & 90 & 28.7 \\
\hline & Insect Pest Control & 136 & 43.3 \\
\hline & Weeds Control & 24 & 7.6 \\
\hline & No Problem & 22 & 7.0 \\
\hline \multirow{3}{*}{$\begin{array}{l}\text { Do you facing any pest } \\
\text { infestation in your field? }\end{array}$} & Yes & 244 & 77.7 \\
\hline & No & 46 & 14.6 \\
\hline & No Idea & 24 & 7.6 \\
\hline
\end{tabular}

Most of the respondents were males as they represent almost $77.7 \%$, compared to only $22.3 \%$ of females. A total of $39.2 \%$ of respondents with income per month between RM1,001 to RM2,000. For $27.4 \%$ of respondents, getting monthly income between RM2,001 to RM3,000. Besides that, $26.1 \%$ of the respondents with monthly income less than RM1,000 and 5.4\% of respondents with monthly 
income between RM3,001 to RM4,000. While, only $1.0 \%$ of the respondents having income between RM 4001 to RM 5000 or more than RM 5001.

Most of the respondents are part time smallholders (57.6\%) compared to only $42.4 \%$ are full time. Majority of the respondents are Chinese (61.5\%) followed by Malay (28.3\%) and Indian (10.2\%). In terms of the education level, $47.5 \%$ of respondents possessed secondary school qualification followed by $47.1 \%$ who had primary school qualification. Only a small number of respondents $(5.4 \%)$ had higher education qualification of college or university.

In term of farm management experience, most of the respondents (56.4\%) having between 10 to 20 years of experience in managing their field, followed by $17.8 \%$ of the respondents having experience in managing their field between 21 to 30 years. While, $17.2 \%, 6.4 \%$ and $2.2 \%$ of respondents having experience in managing field less than 10 years, between 31 to 40 years and more than 40 years, respectively.

The mean field holding size of respondents were 2.52 ha as $37.3 \%$ of respondents having an overall field size of 1.55 to 2.55 ha and followed by $22.0 \%$ of respondents with field holding size of 2.56 to 3.55 ha. Besides that, $21.3 \%$ and $12.1 \%$ of respondents having field holding size of less than 1.55 ha and greater than 4.55 ha, respectively. Only $7.3 \%$ of the respondents having field size of between 3.56 ha to 4.55 ha.

Based on field location, most of the respondents (58.9\%) having field located between $1-10 \mathrm{~km}$ from their house. About $22.0 \%$ of respondents with field located less than $1 \mathrm{~km}$ from their house. While, $18.5 \%$ of respondents with field location between $11-20 \mathrm{~km}$ from house. None of the respondents have field located more than $20 \mathrm{~km}$ from their house.

Majority of the respondents (32.5\%) visiting the field between 1 to 2 times in a month and followed by $28.0 \%$ of respondents going to the field between 3 to 4 times in a month. While, $23.9 \%$ of respondents visiting their field more than 5 times in a month. Only $15.6 \%$ of respondents visiting their field between 4 to 5 times in a month.

Based on respondent feedback regarding major problem in oil palm managements in their field, $43.3 \%$ of the total respondents having problem in pest control techniques and followed by disease control techniques $(28.7 \%)$. While, $13.4 \%$ and $7.6 \%$ of respondents having difficulty in fertilizer and weeds control techniques, respectively. Only $7.0 \%$ of respondents did not face any problem in managing the oil palm in their field. Among respondents, majority of them (77.7\%) answered that they knew about pest infestation in their field and $14.6 \%$ of them answered that they don't know about pest infestation problem in their field. Only $7.6 \%$ of the respondents answered that they are not aware of pest infestation problems in their field.

\section{Level of knowledge on bagworm in oil palm and its control using IPM practices among oil palm independent smallholders}

Table 2 showed the correct and incorrect answers by the respondents based on a total of 17 questions related to bagworm and its control using IPM practices. Almost all the respondents (99.0\%) know that the occurrence of bagworm infestation in their field. Similarly, a total of $98.4 \%$ of respondents know types of oil palm pests. Besides that, $97.1 \%$ of respondents know the types of beneficial plants which can be used as a host for natural enemies such as predators. Only $28.0 \%$ of respondents have seen the $B t$ spraying using light aircraft.

Based on the percentage of incorrect answers, most of the respondents $(72.0 \%)$ did not ever seen the use of pheromone traps to control bagworms. Furthermore, a total of $69.4 \%$ of them did not ever seen $B t$ spraying applied using light aircraft. While, $64.3 \%$ of the respondents are not know that bagworms could possibly attack any other crops other than oil palm. Only $1.0 \%$ of the respondents did not know that the major factor causing bagworm infestation. Based on the answers, it can be concluded that most 
of the respondents have a basic understanding on bagworm in oil palm and its control using IPM practices.

Almost all the respondents $(88.9 \%)$ answered Yes for the question Is it possible for the utilization of chemical pesticide to affect environment and harm the users and followed by $11.1 \%$ of the respondents answered No for the question. Similarly, a total of $87.6 \%$ of the respondents answered Yes for the question Do the utilization of chemical pesticide practicable, quick, effective and easy to be found and only $12.4 \%$ answered No for this question. Besides that, $77.4 \%$ of the respondents answered Yes for the question Are you interested in learning more about pest control in palm oil and $22.6 \%$ of the respondents answered No for this question.

The study also found that $63.7 \%$ of independent smallholders attended courses on pest management organized by MPOB. About $70 \%$ have met with local TUNAS officers for consultation on oil palm management. More than $77 \%$ of independent smallholders are interested to learn more about pest managements.

Majority of respondents (87\%) seem to be aware that utilization of chemical pesticides could possibly affected the environment and harm the users. They were also aware that the utilization of chemical pesticides is practicable, quick, effective and easily found.

Table 2: Level of Knowledge on Bagworm and Its Control Using IPM Practices Among The Independent Oil Palm Smallholders

\begin{tabular}{|c|c|c|c|c|c|}
\hline \multirow{3}{*}{ No } & \multirow{3}{*}{ Questions/Statements } & \multicolumn{4}{|c|}{$\begin{array}{c}\text { Knowledge level of Bagworm in Oil } \\
\text { Palm }\end{array}$} \\
\hline & & \multicolumn{2}{|c|}{ Correct answer } & \multicolumn{2}{|c|}{ Incorrect answer } \\
\hline & & $\mathbf{N}$ & $\%$ & $\mathbf{n}$ & $\%$ \\
\hline 1 & What types of oil palm pests that you know? & 309 & 98.4 & 5 & 1.6 \\
\hline 2 & $\begin{array}{l}\text { Have you ever heard about the infestation of oil } \\
\text { palm pest, that is bagworms? }\end{array}$ & 288 & 91.7 & 26 & 8.3 \\
\hline 3 & $\begin{array}{l}\text { Have you ever seen any oil palm plant infested by } \\
\text { bagworms? }\end{array}$ & 291 & 92.7 & 23 & 7.3 \\
\hline 4 & What is the major factor of bagworm infestation? & 311 & 99.0 & 3 & 1.0 \\
\hline 5 & $\begin{array}{l}\text { Can you identify type of bagworms which cause } \\
\text { damage to your oil palm through these pictures? }\end{array}$ & 299 & 95.2 & 15 & 4.8 \\
\hline 6 & What are the methods of bagworms spread? & 304 & 96.8 & 10 & 3.2 \\
\hline 7 & $\begin{array}{l}\text { What is the possible age of oil palm to be infested } \\
\text { by bagworms? }\end{array}$ & 177 & 56.4 & 137 & 43.6 \\
\hline 8 & $\begin{array}{l}\text { Is it possible for bagworms to attack any other crops } \\
\text { other than oil palm? }\end{array}$ & 112 & 35.7 & 202 & 64.3 \\
\hline 9 & $\begin{array}{l}\text { Is it possible for the bagworms infestation to cause } \\
\text { any yield loss? }\end{array}$ & 302 & 96.2 & 12 & 3.8 \\
\hline 10 & $\begin{array}{l}\text { What are the common symptoms on oil palm } \\
\text { infested by bagworms? }\end{array}$ & 299 & 95.2 & 15 & 4.8 \\
\hline 11 & What bagworm control measures that you know? & 277 & 88.2 & 37 & 11.8 \\
\hline 12 & $\begin{array}{l}\text { Can you identify type of beneficial plants which can } \\
\text { be used as hosts for predators as picture shown } \\
\text { below? }\end{array}$ & 305 & 97.1 & 9 & 2.9 \\
\hline 13 & $\begin{array}{l}\text { Have you ever grown those beneficial plants in your } \\
\text { field? }\end{array}$ & 150 & 47.8 & 164 & 52.2 \\
\hline 14 & Have you ever seen those beneficial plants before? & 244 & 77.7 & 70 & 22.3 \\
\hline 15 & $\begin{array}{l}\text { Have you ever } B t \text { spraying using light aircraft } \\
\text { before? }\end{array}$ & 96 & 30.6 & 218 & 69.4 \\
\hline 16 & $\begin{array}{l}\text { Have you ever seen the pheromone trap used in the } \\
\text { control? }\end{array}$ & 88 & 28.0 & 226 & 72.0 \\
\hline
\end{tabular}




\begin{tabular}{clcccc}
\hline 17 & $\begin{array}{l}\text { Do you feel that bagworms infestation is something } \\
\text { serious? }\end{array}$ & 285 & 90.8 & 29 & 9.2 \\
18 & $\begin{array}{l}\text { Have you ever attend any courses on pest control } \\
\text { organized by MPOB? }\end{array}$ & 200 & 63.7 & 114 & 36.3 \\
19 & $\begin{array}{l}\text { Have you ever meet any local TUNAS officer for } \\
\text { consultation on oil palm management? }\end{array}$ & 218 & 69.4 & 96 & 30.6 \\
20 & $\begin{array}{l}\text { Is it possible the utilization of chemical pesticides } \\
\text { affected environment and harm the users? }\end{array}$ & 279 & 88.9 & 35 & 11.1 \\
21 & $\begin{array}{l}\text { Do the utilization of chemical pesticides is } \\
\text { practicable, quick, effective and easy to be found? } \\
\text { Are you interested in learning more about pest } \\
\text { control in palm oil? }\end{array}$ & 275 & 87.6 & 39 & 12.4 \\
\hline
\end{tabular}

The level of respondent's knowledge was categorized according to the scale of 1) Low - less than 50\%, 2) Moderate $-50 \%$ to $80 \%$ and 3 ) high - more than $80 \%$. Table 3 showed that majority of the respondents $(57.0 \%)$ have low level of knowledge regarding bagworm and its control using IPM practices among independent smallholders in the oil palm area. A total of $38.9 \%$ of them having a moderate level of knowledge and only $4.1 \%$ have high a level of knowledge.

Table 3: Level of Knowledge on Bagworm and Its Control Using IPM Practices Among Independent Oil Palm Smallholders

\begin{tabular}{lllll}
\multicolumn{1}{c}{ Knowledge level } & \multicolumn{1}{c}{$\begin{array}{c}\text { Frequency } \\
\text { (n) }\end{array}$} & \multicolumn{1}{c}{$\begin{array}{c}\text { Percentage } \\
(\%)\end{array}$} \\
\hline Low $(<50 \%)$ & 179 & & 57.0 & \\
Moderate $(50 \%$ to $80 \%)$ & 122 & & 38.9 & \\
High $(>80 \%)$ & 13 & & 4.1 & \\
\hline
\end{tabular}

Mean: 1.47; S.D: 0.577; n: 314; n= number of respondents

\section{Relationship between selected variables with the level of knowledge on bagworm and its control using IPM practices among independent oil palm smallholders}

Pearson product-moment correlation analysis were conducted to identify the relationship between selected variables with the level of knowledge on bagworm and its control using IPM practices among the independent oil palm smallholders (Table 4). Results revealed that out of 10 variables, three variables have a significant relationship with the level of knowledge on bagworm and its control using IPM practices. These variables are race $(r=0.138)$, education level $(r=0.165)$, experience in field $(r=$ 0.135). Variables such as age, gender, monthly income, status, field holding size, distance field from house and frequency of field visit did not have any significant relationship with the level of knowledge on bagworm and its control using IPM practices among independent oil palm smallholders.

Table 4: Pearson Correlation Analysis Between Selected Variables with The Level of Knowledge on Bagworm and Its Control Using IPM Practices Among Independent Oil Palm Smallholders

\begin{tabular}{lc}
\hline Variables & $\begin{array}{l}\text { Correlation } \\
\text { coefficient } \\
(\mathbf{r})\end{array}$ \\
\hline Age & 0.003 \\
Gender & -0.080 \\
Monthly Income & 0.035 \\
Status & 0.030 \\
Race & $0.138^{*}$ \\
Education Level & $0.165^{* *}$ \\
Experience in Field Management & $0.135^{*}$ \\
Field holding Size & 0.025 \\
Distance Field from House & 0.070
\end{tabular}


Frequency of Field Visit $-0.018$

What are the Major Problem in Term of Oil Palm Maintenance in Field $0.123^{*}$

Do you Face any Pest Infestation Problem in your Field $-0.269 * *$

**Correlation is significant at $\mathrm{P}=0.01$ (2-tailed)

*Correlation significant at $\mathrm{P}=0.05$ (2-tailed)

\section{Descriptive analysis on the advantages of implementing integrated pest management practices for bagworms in field}

Table 5 demonstrated the mean and standard deviation for item representing the advantages of implementing IPM practices for bagworms in the field owned by independent oil palm smallholders in Johor. The analysis showed that the higher mean scores was recorded on advantage that IPM will reduce pollution problem $(\mathrm{M}=3.90, \mathrm{SD}=0.634)$, followed by item on reducing long-term pest management cost $(M=3.84, S D=0.578)$, then reducing pesticide utilization $(M=3.79, S D=0.650)$ and easy to be practiced in the field $(\mathrm{M}=3.79, \mathrm{SD}=0.620)$. Item on advantage IPM is safe to farmers $(\mathrm{M}=3.78, \mathrm{SD}=0.643)$ recorded the lowest score than other item. The overall mean score for what are the advantages of implementing IPM practices for bagworms in field was $\mathrm{M}=3.82(\mathrm{SD}=0.625)$.

Table 5: Descriptive Analysis on The Advantages of Implementing Integrated Management System for Bagworm in Your Field

\begin{tabular}{llll}
\hline No & Item & Mean & Std. Deviation \\
\hline 1. & Reduce pesticide utilization & 3.79 & 0.650 \\
2. & Reduce pollution problem & 3.90 & 0.634 \\
3. & Easy to be practiced in the field & 3.79 & 0.620 \\
4. & Safe for farmers & 3.78 & 0.643 \\
5. & Reduce long-term pest management cost & 3.84 & 0.578 \\
\hline Overall & $\mathbf{3 . 8 2}$ & $\mathbf{0 . 6 2 5}$ \\
\hline
\end{tabular}

\section{Descriptive analysis on the possible problems in implementation of IPM practices for bagworms in field}

Table 6 demonstrated the mean and standard deviation for item representing the possible problems in implementing IPM practices for bagworms in the respondent field. The highest mean score for possible problems in implementing IPM by independent oil palm smallholders was related that IPM needed high commitment to be implemented $(\mathrm{M}=3.71, \mathrm{SD}=0.604)$ and followed by the IPM operators required high level of knowledge and skills $(\mathrm{M}=3.67, \mathrm{SD}=0.563)$. The third higher mean score was on item showing that the system was difficult to be practiced $(\mathrm{M}=3.37, \mathrm{SD}=0.731)$. Finally, the lowest mean score was recorded on information of IPM system was not easily available causing difficultly to be found $(\mathrm{M}=3.33, \mathrm{SD}=0.648)$. The overall mean score for the possible problems in implementing IPM practices was $\mathrm{M}=3.52(\mathrm{SD}=0.637)$.

Table 6: Descriptive Analysis on The Possible Problems of Implementing IPM Practices for Bagworms in Field

\begin{tabular}{llll}
\hline No & Item & Mean & Std. Deviation \\
\hline 1 & This system is difficult to be practiced & 3.37 & 0.731 \\
2 & Information of this system is difficult to be found & 3.33 & 0.648 \\
3 & This system needs high commitment to be & 3.71 & 0.604 \\
4 & implemented & 3.67 & 0.563 \\
\hline Overall & $\mathbf{3 . 5 2}$ & $\mathbf{0 . 6 3 7}$ \\
\hline
\end{tabular}




\section{Conclusion}

The study revealed that most of the independent oil pam smallholders have a basic knowledge on bagworm in oil palm and its IPM practices. Their level of knowledge however still at a low level. Several factors have been found to have a significant relationship between the level of knowledge on bagworm and its IPM practices. These factors included race, education level and experience in field management. Therefore, services by extension agents need to be more focused on these factors to further enhance the level of knowledge of the smallholders to adopt the effective bagworm control practices, especially using IPM approaches. It is recommended that extension agents need to be available and frequently meeting smallholders distributing related information on oil palm pest management. On top of that the comprehensive training modules on bagworm management need to be introduced to smallholders especially those who are having badly affected oil palm areas by bagworm. During the writing period, guidelines such as pamphlets and posters using Malay and Mandarin language for plant infected with bagworm and the symptoms have been prepared and distributed to all TUNAS. TUNAS officers were advised to distribute the information to smallholders in enhancing their knowledge. This effort hopefully will help to reduce the spread of bagworm to other smallholder oil palm areas.

\section{Recommendation}

Identifying one or two smallholders who have successfully implemented IPM in controlling bagworm infestation to share their experiences in handling and controlling the bagworm during technical training. A rescue team should be formed to communicate with the technical team on the bagworm attack to make sure the knowledge and controlling methods are successfully implemented on the site infected. Further study should focus in identifying other constraints faced by smallholders in managing bagworm infestation and its control such cost of application, availability of technology, availability of resources and others.

\section{Acknowledgment}

We are grateful to Malaysian Palm Oil Board (MPOB) for their support in conducting this research. We also thank all independent oil palm smallholders who participated in this study.

\section{References}

Basri, M. W., Abdul, H. H. \& Masijan, Z. (1988). Bagworms (Lepidoptera : Psychidae) of oil palms in Malaysia. PORIM Occasional Paper, 23.

Basri, M. W. (1993). Life history, ecology and economic impact of the bagworm, Metisa plana Walker (Lepidoptera: Psychidae) on the oil palm, Elaeis guineensis Jacouin. (Palmae), in Malaysia (p.231). Ph.D. Thesis, University of Guelph

Basri, M. W., Norman, K., \& Hamdan, A. B. (1995). Natural enemies of the bagworm, Metisa plana Walker (Lepidoptera: Psychidae) and their impact on host population regulation. Crop Protection, 14, 637-645.

Charles, D. H. (2008). Integrated management practices for oil palm bagworms in Papua, New Guinea.

Kalidas, P. (2012). Pest problems of oil palm and management strategies for Sustainability. Agrotechnol S11.001

Krejcie, R. V. \& Morghan, D. W. (1970). Determining sample size for research activities. Educational and psychological Measurements, 30, 607-610.

Maho, Y. J. E \& Godswill, N. N. (2008). Development of integrated pest management system in agricultural production in Cameroon and the Central African Sub Region. 
Morin, J. P. \& D. Mariau (1971). The study of biology of Coelaenomenodera elaieides Mlk.III. Reproduction, 26:373-378.

MPOB (2018). Oil Palm Statistic, MPOB.

Norman, K. \& Basri, M. W. (2007). Status of common insect pest in relation to technology adoption. The Planter, 83, 371-385

Norman, K. \& Basri, M. W. (1992). A survey of current status and control of nettle caterpillars (Lepidoptera:Limacodidae) in Malaysia (1981-1990). PORIM Occasional paper No. 27.

Sankaran, T. \& Syed, R. A. (1972). The natural enemies of bagworms on oil palms in Sabah, East Malaysia. Pacific Insects, 14, 57-71. 